\title{
A Systematic Literature Review on Hospitality Analytics
}

\author{
João Paulo Rodrigues, Universidade Europeia, Portugal \\ Maria José Sousa, Instituto Universitário de Lisboa, Portugal \\ Ana Brochado, Instituto Universitário de Lisboa, ISCTE-IUL, Portugal \& Centre for Socioeconomic and Territorial \\ Studies, DINÂMIA'CET - IUL, Portugal
}

\begin{abstract}
With the growth of data generated by all systems involved in a hotel, terms like big data and business analytics (BA) gain strength within the hotel industry. Business analytics can be used in hospitality management to increase business knowledge and to improve the decision-making process. This study's main questions are: RQ1 - Which are the main research attributes studied in the past two decades related to analytics in the hospitality sector? RQ2 - What are the main differences between business intelligence and business analytics? RQ3 - What are the main trends in business analytics? RQ4 - Which are the main business intelligence perceptions and beliefs? To answer these research questions, this article provides a literature review to systematize the research made in business analytics information systems in the hospitality industry. The results can help identify different research attributes and the most relevant theories developed in the past two decades related to business analytics tools.
\end{abstract}

\section{KEYWORDS}

Analytics, Business Analytics, Hospitality, Hotels, Literature Review

\section{INTRODUCTION}

Nowadays, there is a wide variety of information systems in which the tourism and hotel industry have not stayed behind. With the accelerated growth of the Internet, everything has been boosted, where new apps of all types and genres arise all the time. This growing digital economy has attracted the attention of computer engineers and hotel managers, either by for the confusing choice for new operating systems and how they will all integrate to be able to extract information as a whole or how can managers be able to analyze volumes of information generated by these systems. Last year has witnessed significant changes, such as the transformation from non-digital services to digital services (Abbasi, Ahmed; Sarker, Suprateek; and Chiang, 2016).

Also, the data type is no longer merely text-structured data, but rather images, audio, video, and social media content, referred to as unstructured data (Lam, Sleep, Hennig-Thurau, Sridhar, \& Saboo, 2017). With modern technology, new types of data and advanced analytical tools provide firms both opportunities and challenges (Raguseo, 2018).

\section{DOI: 10.4018/IJBIR.20200701.oa2}

This article published as an Open Access article distributed under the terms of the Creative Commons Attribution License (http://creativecommons.org/licenses/by/4.0/) which permits unrestricted use, distribution, and production in any medium, provided the author of the original work and original publication source are properly credited. 
The challenge for hotel managers is to be able to store these significant volumes of data in a way that, through analytics tools, provides information that adds value to the business and helps, based on the analyzed patterns, on a better decision making and in the best knowledge of their business.

As hotels operate in a competitive and dynamic environment, hotels need to utilize information effectively in order to improve hotel performance and compete with other hotels (Berezina, Bilgihan, Cobanoglu, \& Okumus, 2016). The hotel sector, although not one of the sectors of activity that most embraces the use of analytical technologies, has begun to realize its value and importance in identifying usage trends and decision making (Korte, 2013) Through the literature it is possible to realize that companies that have implemented analytical systems can obtain better performances through wiser, more accurate and quicker decisions.

To understand analytics, we need to focus first on the various types of systems that a hotel can have and how they integrate and next in how analytical systems can help define strategies and improve decision making based on analytical models and key performance indicators. To achieve this goal, it is essential to approach the theme of integrating the various information systems used in a hotel, since it is difficult to achieve the objective, which is to have all the information gathered and compiled to know the business better and take with these better decisions.

This paper is structured as follows: the next section frame business intelligence (BI) and analytics and discuss business analytics trends.

\section{MATERIALS AND METHODS}

A systematic search of online scientific databases using the platform Ebsco-host, a scientific information research tool, was conducted at the beginning of April 2019. The search was made using several queries containing the keywords "Data Analytics" and "Hospitality." The first results were 16,934 articles. The inclusion of the time criteria "2000-2019" and "Scientific Reviews" 1,667 articles were listed. Only the articles reporting precise empirical data and a scientific methodology were considered for a more in-depth review (286) (Figure 1), and after exclusion of the articles which

\section{Figure 1. Flowchart outlining the literature review}

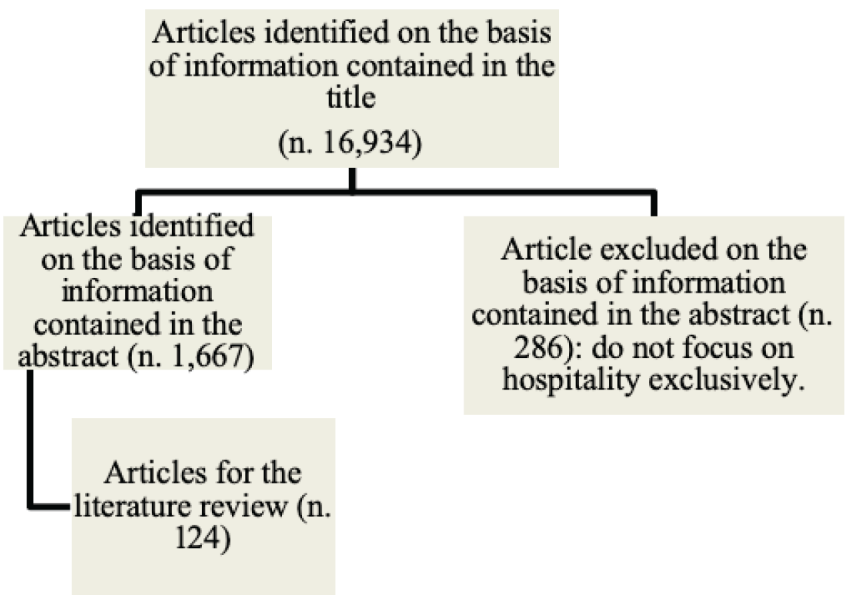

do not focus exclusively in Hospitality was listed 124 articles. The articles selected for this systematic review are presented in Annex 1, containing information regarding the bibliographical reference of the publication, the primary attributes researched, and the key findings. 
Table 1 is shown with the summary of the research attribute referred in the articles analyzed at least ten times.

This analysis answers to the first research question (RQ1) What are the main research attributes studied in the past two decades, related to analytics in the hospitality sector? Being the answer: Big Data Analytics, Social media, Big data, Tourism, Social media analytics. Online reviews, Artificial intelligence, Sharing economy, Customer Relationship Management, Text Analytics, Data Mining.

Table 1. Research attributes

\begin{tabular}{|l|l|}
\hline \multicolumn{1}{|c|}{ Research Attribute } & \multicolumn{1}{c|}{$\mathbf{n}$} \\
\hline Big Data Analytics & 39 \\
\hline Social media & 20 \\
\hline Big data & 16 \\
\hline Tourism & 15 \\
\hline Social media analytics & 14 \\
\hline Online reviews & 14 \\
\hline Artificial intelligence & 12 \\
\hline Sharing economy & 10 \\
\hline Customer Relationship Management & 10 \\
\hline Text analytics & 10 \\
\hline Data Mining & 10 \\
\hline
\end{tabular}

The analysis of the network of the articles can be found in Figure 2, which summarizes the research attributes for this analysis.

Figure 2. Network of the research attributes

20 - social`media

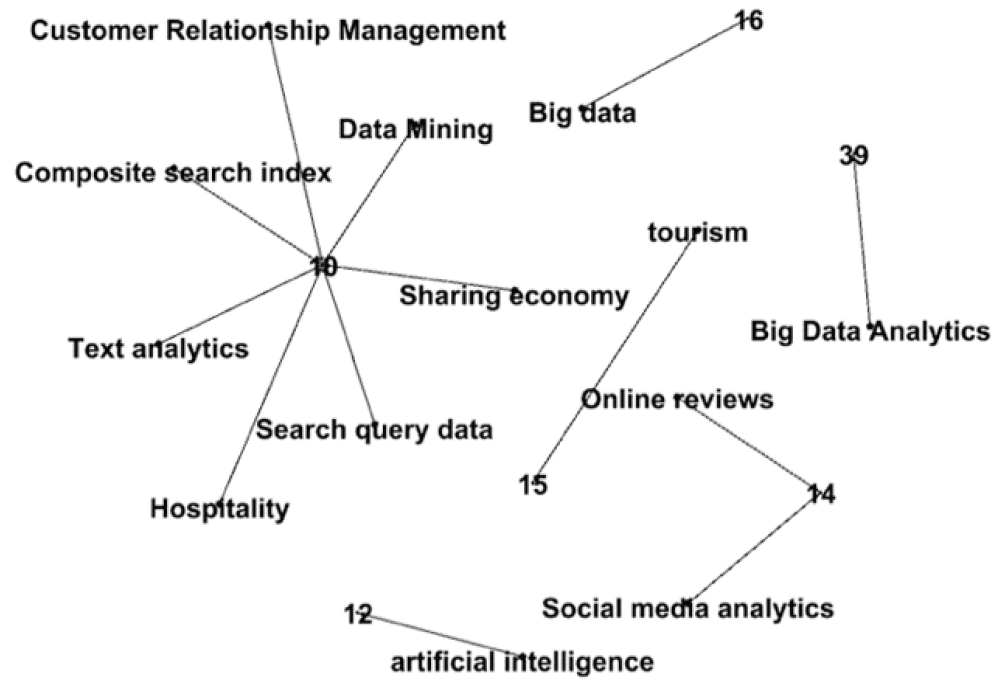




\section{LITERATURE REVIEW ON BUSINESS ANALYTICS IN HOSPITALITY - INSIGHTS FROM THE RESEARCH}

When we have the right technology at your disposal, and it is entirely available and properly applied, a top manager can take visible and meaningful organizational benefits and thereby be able to promote the company's growth in line with market developments (Rodolfo, 2015).

Business intelligence and analytics are contextualized in terms of exchange because it is identified that various exchange activities take place within the BI environment throughout the BI process, like processes to transform raw data into useful information for insights and decisionmaking (Duan \& Xu, 2012).

\subsection{Business Intelligence and Business Analytics}

The term business intelligence and analytics emerged in 1990 and has been gaining strength in the community of IT professionals and academia over the past decades. Since the last 20 years, we have seen a significant focus on technology but nothing like after the year 2000, where we have witnessed the genuinely transformative effect of communication technologies (Azevedo, Azevedo, \& Romão, 2014). The importance of information and, as a consequence, business analytics has become latent and has gained focus in these recent years. Turban, Sharda, \& Delen, (2011) states that business intelligence is an umbrella term that combines architectures, databases, analytical tools, methodologies, and applications to aid in decision-making processes.

Emerges then the second research question (RQ2) What are the main differences between Business Intelligence and Business Analytics?

According to (Vajirakachorn \& Chongwatpol, 2017), business intelligence and business analytics have drawn attention in both academic and business communities over the past decades. (Power, Heavin, McDermott, \& Daly, 2018) refers to business analytics as a compound noun, and one would expect its meaning to be anchored in the two independent concepts of "business" and "analytics." They designate analytics as a broad umbrella term that includes business analytics and data analytics. Analytics is the progenitor concept for the compound word phrase "Business Analytics."

(Chen, Chiang, \& Storey, 2012) outlines that organizations view both BI and BA in different ways, from tools, techniques, technologies, and systems to practices, methodologies, and applications that help enterprises make better and more timely decisions by analyzing critical business data (Cooper M., Thai L.Q., Claster W., Vafadari K., 2015). According to (Power et al., 2018), at some level of generalization, business analytics is the application of analytics to business problems.

Stubbs (2014), refers to business analytics as an application of relevant, measurable knowledge to strategic and tactical business objectives through data-based decision making. (Goes, 2014) adds that analytics refers to the higher stages in the data-knowledge continuum and is directly related to decision support systems and define business analytics as "the generation of knowledge and intelligence to support decision making and strategic objectives"(Goes, 2014).

Business analytics refers to the extensive use of data and quantitative analysis, usually grounded in data mining and statistical analysis, to develop new insights and understand business performance (Chen et al., 2012; Davenport, 2010).

The tourism sector is also data-hungry, for having the right information at the right time provides businesses with knowledge about customers, buying behavior, and market trends (Cooper, 2006) and hotel managers understand the importance of adapting to the changing business environment not only to remain competitive, but merely to survive (Magnini, Honeycutt, \& Hodge, 2003). However, given the importance and complexity of data analytics and Business Intelligence analyses, senior hotel managers report a low level of understanding about those systems capabilities, how it works, and what value this technology contributes.

According to Hallin \& Marnburg (2008), analytical systems have had a strong presence in the management concepts debate in the last decade; however, in the hospitality industry, this subject has 
not yet reached the same dimension. The practice and study of Business Intelligence have proliferated in most industries, except the tourism and hospitality sector (Cooper, 2006; Yun, 2004; Ruhanen \& Cooper, 2004). In the hotel industry, only a small number of hotels have implemented analytical systems and knowledge management. Yun (2004), argues that the tourism and hospitality industry adapts slowly to Business Intelligence strategies.

\subsection{Business Analytics Trends}

With the accentuated tourism grow, companies and hotels need to deal with a large amount of data, and today the business environment has to make quicker decisions than ever (Chen et al., 2012). In this section then studies the third research question (RQ3) topic: What are the main trends of Business Analytics? To answer that question, the literature review concludes that three critical trends are linked to the investigation of the relationship between BI implementation success, organizational culture, and decision making.

First, the number of firms investing in BI has dramatically increased in recent years (Gartner, 2017). Over the last two decades, organizations have grown increasingly dependent upon BI systems to increase the effectiveness of decision making. New technologies and reduced costs have enabled companies, regardless of firm size, to purchase BI technologies (Gartner, 2017).

As a consequence, BI systems have evolved into sophisticated IT solutions designed to manage a wide variety of data and to provide analytical tools to assist management in decision-making. The financial risks associated with IT use by both large and small enterprises are of greater relevance not only due to direct technology acquisition costs but also due to the high implementation expenses associated with time away from productive work in the form of downtime or training (Lippert \& Swiercz, 2005). As such, understanding the factors that impact successful implementation has economic implications regardless of organizational size.

Second, the inclusion of BI functionality within full-service software technologies places additional burdens on all personnel on how to learn and integrate the full range of functions embedded within these systems.

The third is the emergence of trust implications. Organizational members at all levels can quickly and efficiently access data while managers and supervisors can use the information for decision making.

\subsection{Business Intelligence Perceptions and Beliefs}

Business Intelligence is highly promoted and praised, yet not all expectations are realized. Instead, numerous reports of failed BI implementations and challenges prevail (Clavier, Lotriet, \& Van Loggerenberg, 2012). Strong beliefs are set for BI and are systematically ranked as a top priority globally. Unfortunately, not all organizations are well succeeded in realizing superior business value from their BI investments. BI has failed to become widely pervasive (Gartner, 2008).

In this context, the fourth research question emerges (RQ4), which are the leading Business Intelligence Perceptions and Beliefs?

According to Magnini et al. (2003), hotel managers understand the importance of adapting to the changing business environment not only to remain competitive but merely to survive. As a result, technology has become massive. Moreover, consequently, technology has become a large and growing expense for many hotel corporations. However, given the importance and complexity of business intelligence and data mining processes, senior hotel managers report a low level of understanding about its capabilities, how it works, and what value this technology contributes (Magnini et al., 2003).

As mentioned by (Fuchs, Höpken, \& Lexhagen, 2014), literature only recently emphasizes BI and data management for knowledge creation in travel and tourism (Fuchs, Matthias \& Höpken, 2009; Magnini et al., 2003; Min, Min \& Emam, 2002; Morales \& Wang, 2008; Palmer, José Montaño, \& Sesé, 2006 and Wong, Chen, Chung, \& Kao, 2006). For tourism destinations, only few BI studies exist (Fuchs, Abadzhiev, Svensson, Höpken, \& Lexhagen, 2013; Fuchs et al., 
2011; Law, Rob, 20111; Ricci, 2011; Fuchs, Matthias, 2014; Höpken, W., 2014; Zanker, M., 2014 and Beer, 2014). However, being part of the service sector, tourism has inevitably been associated with developments in new technologies and refreshed by organizational and structural innovations (Stamboulis \& Skayannis, 2003).

Nowadays, it begins to be commonly used the term Big Data which represents a massive volume of structured and unstructured data, and it is increasingly difficult processing this massive volume through the use of traditional software techniques or by using traditional statistical methods (Baggio, 2016). Big Data has also started to be a source for Business Intelligence activities. The tradition of BI analytics is more significant, but the field is susceptible to all data and information sources that can provide a better return on the investment (Liebowitz, 2013). Therefore, both subjects are highly complementary.

Hotel managers understand the importance of adapting to the changing business environment not only to remain competitive but merely to survive. As a result, technology has become a large and growing expense for many hotel corporations. Under such a technology framework, business intelligence and data mining is a valuable competitive tool being adopted by hotel corporations to create customer value (Magnini et al., 2003).

$\mathrm{BI}$ and data mining can be a powerful and valuable marketing tool. However, merely investing in business intelligence technology may not guarantee success. Finding a database expert who has experience creating models in the hotel industry is a significant benefit. With this, we are facing organizational learning where the processes of creation and acquisition of knowledge can be significantly improved through the application of Business Intelligence methods.

\section{CONCLUSION}

Hospitality and tourism industry is experiencing great and exciting challenges, because of the future capabilities of the latest technologies and the possibilities that await the industry as a result of the implementation of new technologies. Investing in technology can not only be seen as an expense but rather as an important investment in future competitiveness. The sooner this is realized, the sooner the hotel industry will begin to take great strides in its quest to become technologically advanced.

Guess the future can be a tremendous and frightening challenge, since everything around us spins at the speed of light, often misrepresenting our own vision. Even though it is scary and risky, it has to be seen as a requirement to survive in this complex and super competitive world.

Foresight is not something that the hospitality industry has done especially well in the past, as the industry is more reactive than proactive. Developing skills in the vision of the future is essential today for tomorrow's survival.

Beyond technology, the biggest challenge lies in people and in their way of thinking, acting and making decisions. The hotel industry, by tradition, does not excel in investing heavily in technology, but will have to do so in order to gain some competitive advantage. 


\section{REFERENCES}

Abbasi, A., Sarker, S., \& Chiang, R. (2016). Big Data Research in Information Systems: Toward an Inclusive Research Agenda. Journal of the Association for Information Systems, 17(2), 3. doi:10.17705/1jais.00423

Azevedo, P. S., Azevedo, C., \& Romão, M. (2014). Application Integration: Enterprise Resource Planning (ERP) Systems in the Hospitality Industry. A case study in Portugal. Procedia Technology, 16, 52-58. doi:10.1016/j. protcy.2014.10.067

Baggio, R. (2016). Big Data, Business Intelligence, and Tourism: a brief analysis of the literature. Big Data \& Business Intelligence in the Travel \& Tourism Domain, 1-7. 10.1016/j.tourman.2015.10.008

Berezina, K., Bilgihan, A., Cobanoglu, C., \& Okumus, F. (2016). Understanding Satisfied and Dissatisfied Hotel Customers: Text Mining of Online Hotel Reviews. Journal of Hospitality Marketing \& Management, 25(1), 1-24. doi:10.1080/19368623.2015.983631

Chen, H., Chiang, R. H. L., \& Storey, V. C. (2012). Business Intelligence and Analytics: From Big Data to Big Impact. Management Information Systems Quarterly, 36(4), 1165-1188. doi:10.2307/41703503

Clavier, P. R., Lotriet, H. H., \& Van Loggerenberg, J. J. (2012). Business Intelligence challenges in the context of Goods- and Service-Dominant Logic. Proceedings of the Annual Hawaii International Conference on System Sciences, 4138-4147. doi:10.1109/HICSS.2012.138

Cooper, C. (2006). Knowledge management and tourism. Annals of Tourism Research, 33(1), 47-64. doi:10.1016/j. annals.2005.04.005

Cooper, M., Thai, L. Q., Claster, W., \& Vafadari, K. P. P. (2015). Knowledge Transfer in the Tourism Industry: Implications of the Use of Social Media in Business Analysis. Journal of Hospitality and Tourism, 13(1), 1-15. www.johat.org

Davenport, T. H. (2010). The New World of Business Analytics. SAS Institute, 1-5.

Davis, F. D., Bagozzi, R. P., \& Warshaw, P. R. (1989). User Acceptance of Computer Technology: A Comparison of Two Theoretical Models. Management Science, 35(8), 982-1003. doi:10.1287/mnsc.35.8.982

Duan, L., \& Da Xu, L. (2012). Business intelligence for enterprise systems: A survey. Industrial Informatics. IEEE Transactions On, 8(c), 1-9. doi:10.1109/tii.2012.2188804

Fuchs, M., \& Höpken, W. (2009). Data mining in tourism. Praxis der Wirtschaftsinformatik, 270(12), 73-81. doi:10.1007/BF03340421

Fuchs, M., Höpken, W., Law, R., \& Ricci, F. (2011).026_BI_Information and Communication Technologies in Tourism 2011.pdf. New York: Springer.

Fuchs, M., Höpken, W., Zanker, M., \& Beer, T. (2014). The knowledge destination - Applying methods of business intelligence to tourism. In J. Wang (Ed.), Encyclopedia of Business Analytics and Optimization (pp. 307-321). Academic Press.

Fuchs, M., Abadzhiev, A., Svensson, B., Höpken, W., \& Lexhagen, M. (2013). A Knowledge Destination Framework for tourism sustainability: A Business Intelligence application from Sweden. Tourism (Zagreb), 61(2), 121-148.

Fuchs, M., Höpken, W., \& Lexhagen, M. (2014). Big data analytics for knowledge generation in tourism destinations - A case from Sweden. Journal of Destination Marketing \& Management, 3(4), $198-209$. doi:10.1016/j.jdmm.2014.08.002

Gartner. (2008). Business Intelligence. Author.

Gartner. (2017). Top strategic technology trends. Retrieved from https://www.gartner.com/smarterwithgartner/ gartner-top-10-strategic-technology-trends-for-2018/

Goes, P. B. (2014). Big Data and IS Research. MIS Quarterly, 38(3), iii-viii.

Hallin, C. A., \& Marnburg, E. (2008). Knowledge management in the hospitality industry: A review of empirical research. Tourism Management, 29(2), 366-381. doi:10.1016/j.tourman.2007.02.019 
Korte, D. (2013). Business Intelligence in the Hospitality Industry. International Journal of Innovation, Management and Technology, 4(4). Advance online publication. doi:10.7763/IJIMT.2013.V4.435

Lam, S. K., Sleep, S., Hennig-Thurau, T., Sridhar, S., \& Saboo, A. R. (2017). Leveraging Frontline Employees' Small Data and Firm-Level Big Data in Frontline Management: An Absorptive Capacity Perspective. Journal of Service Research, 20(1), 12-28. doi:10.1177/1094670516679271

Liebowitz, J. (2013). Big data and business analytics. Boca Raton: CRC Press.

Lippert, S. K., \& Swiercz, P. M. (2005). Human resource information systems (HRIS) and technology trust. Journal of Information Science, 31(5), 340-353. doi:10.1177/0165551505055399

Magnini, V. P., Honeycutt, E. D., \& Hodge, S. K. (2003). Data Mining for Hotel Firms: Use and Limitations. The Cornell Hotel and Restaurant Administration Quarterly, 44(2), 94-105. doi:10.1016/S0010-8804(03)90022-X

Min, H., Min, H., \& Emam, A. (2002). A data mining approach to developing the profiles of hotel customers. International Journal of Contemporary Hospitality Management, 14(6), $274-285$. doi: $10.1108 / 09596110210436814$

Morales, D. R., \& Wang, J. (2008). Passenger Name Record Data Mining Based Cancellation Forecasting for Revenue Management. Innovative Applications of OR, 202, 554-562.

Palmer, A., José Montaño, J., \& Sesé, A. (2006). Designing an artificial neural network for forecasting tourism time series. Tourism Management, 27(5), 781-790. doi:10.1016/j.tourman.2005.05.006

Power, D. J., Heavin, C., McDermott, J., \& Daly, M. (2018). Defining business analytics: an empirical approach. Journal of Business Analytics.

Raguseo, E. (2018). Big data technologies: An empirical investigation on their adoption, benefits, and risks for companies. International Journal of Information Management, 38(1), 187-195. doi:10.1016/j. ijinfomgt.2017.07.008

Rodolfo, B. (2015). Information and communication technology in the hospitality industry. Ereview of Tourism Research, 2(5), 108-114. http://ertr.tamu.edu

Ruhanen, L., \& Cooper, C. (2004). Applying a knowledge management framework for tourism research. Tourism Recreation Research, 29(1), 83-87. doi:10.1080/02508281.2004.11081434

Stamboulis, Y., \& Skayannis, P. (2003). Innovation strategies and technology for experience-based tourism. Tourism Management, 24(1), 35-43. doi:10.1016/S0261-5177(02)00047-X

Stubbs, E. (2014). The value of business analytics: Identifying the Path to Profitability. John Wiley.

Turban, E., Sharda, R., \& Delen, D. (2011). Decision Support And Business Intelligence Systems 9th. Pearson Education.

Vajirakachorn, T., \& Chongwatpol, J. (2017). Application of business intelligence in the tourism industry: A case study of a local food festival in Thailand. Tourism Management Perspectives, 23, 75-86. doi:10.1016/j. tmp.2017.05.003

Venkatesh, V., Morris, M. G., Davis, G. B., \& Davis, . (2003). User Acceptance of Information Technology: Toward a Unified View. Management Information Systems Quarterly, 27(3), 425. doi:10.2307/30036540

Walter, A. (2012). Social Research Methods. Social Research Methods (4th ed.). Oxford University Press inc.

Wong, J. Y., Chen, H. J., Chung, P. H., \& Kao, N. C. (2006). Identifying valuable travelers and their next foreign destination by the application of data mining techniques. Asia Pacific Journal of Tourism Research, 11(4), 355-373. doi:10.1080/10941660600931200

Yun, D. (2004). Knowledge Management in Hospitality and Tourism. Annals of Tourism Research, 31(4), 1063-1065. doi:10.1016/j.annals.2004.04.004 
João Paulo Rodrigues is a PhD student in Tourism Management at ISCTE/UE. He has a master degree in Strategic Management of Tourist Companies and a Degree in Information Technology Management. He is a lecturer at the UE - Universidade Europeia since 2010, where he was also recognized as a Specialist Professor in Hotel Management and Computer Science. At UE, he teaches in areas such as Digital Marketing, ERP, CRM, Business Intelligence and technology Applied to Tourism and Hospitality. He is Marketing Director at Host Hotel Systems, where in the last years he took advantage of his IS / IT skills, channeling them into Tourism and Hospitality. In addition to promoting the Host Hotel Systems brand, he has been in charge of managing the main information systems implementation projects for the Hotel Industry. He was a professor at ESTHE - Estoril Higher School of Tourism and Hospitality and at the Lusófona University, in the areas of Computer Systems and Management and Decision Support Systems related to Tourism and Hospitality. He has been invited to participate as a speaker, moderator and mentor in matters related to Tourism, Innovation and Technologies, namely in Tourism of Portugal.

Maria José Sousa (Ph.D. in Management) is a University Professor and a research fellow at ISCTE/Instituto Universitário de Lisboa. Her research interests currently are public policies, information science, innovation, and management issues. She is a best seller author in ICT and People Management and has co-authored over 70 articles and book chapters and published in several scientific journals (e.g. Journal of Business Research, Information Systems Frontiers, European Planning Studies, Systems Research, and Behavioral Science, Computational and Mathematical Organization Theory, Future Generation Computer Systems and others), she has also organized and peer-reviewed international conferences, and is the guest-editor of several Special Issues. She has participated in several European projects of innovation transfer and is also External Expert of COST Association - European Cooperation in Science and Technology and President of the ISO/TC 260 - Human Resources Management, representing Portugal in the International Organization for Standardization.

Ana Brochado is a professor of management at the ISCTE-IUL-Instituto Universitário de Lisboa - Lisbon University Institute and a researcher at DINAMIA'CET-Centre for Socioeconomic and Territorial Studies. She served as the Vice Dean for administrative affairs and Vice Dean for faculty for five years and coordinated the PhD in Tourism Management. She worked for more than one decade as Senior Economist for the Portuguese Competition Authority and the Securities Commission. She joined the Strategic Board of Compete2020. She has a Bachelor of Science in Economics, a Master of Science in Quantitative Methods, and a Doctor of Management. Her main research interests are market research, hospitality and tourism management, Fintech, sustainability management, and innovation. She has authored or co-authored over 50 publications in top international journals in these fields, wrote over 40 book chapter and presented over 200 talks in international conferences. Her research received over 1000 citations. 